\title{
The comparative studies of Borneo plant extracts to increases vaccine efficacy in tilapia, Oreochromis niloticus
}

\section{Studi perbandingan beberapa ekstrak tumbuhan dari Kalimantan Timur untuk meningkatkan efikasi vaksin pada ikan nila, Oreochromis niloticus}

\author{
Esti Handayani Hardi ${ }^{*}$, Komsanah Sukarti ${ }^{1}$, Maulina Agriandini ${ }^{1}$, Irawan Wijaya \\ Kusuma $^{2}$, Rudi Agung Nugroho ${ }^{3}$ \\ ${ }^{1}$ Microbiology Laboratory, Department of Aquaculture, Faculty of Fisheries and Marine Science, Mulawarman \\ University, East Kalimantan, Indonesia. \\ ${ }^{2}$ Faculty of Forestry, Mulawarman University \\ ${ }^{3}$ Faculty of Science, Mulawarman University \\ *Corresponding author : estieriyadi2011@gmail.com
}

(Received February 20, 2017; Accepted July 19, 2018)

\begin{abstract}
This study investigated the adjuvant effect of Boesenbergia pandurata (BP), Zingiber zerumbet (ZZ), Solanum ferox (SF) on protection of tilapia with injection Pseudomonas sp. (Pseumulvacc) vaccination. The extract concentrations of BP $(600 \mathrm{mg} / \mathrm{L}), \mathrm{ZZ}(200 \mathrm{mg} / \mathrm{L})$, and SF $(900 \mathrm{mg} / \mathrm{L})$ were combined with the vaccine, ratio between vaccine and extract was 1:1. Tilapia fish were injected with vaccine mix the extract and challenged at day 7 (d7), 14 (d14), and 21 (d21) post vaccination through injection with A. hydrophila and P. fluorescens (105 CFU/ $\mathrm{mL}$ each bacteria). The results shown that the fish with $\mathrm{BP}+\mathrm{V}$ were found in fin rot at d14 days challenge. The same symptom was found in $\mathrm{ZZ}+\mathrm{V}$ at $\mathrm{d} 14$ challenge as much $11.11 \%$ and $42.86 \%$ while, in the vaccine groups $(\mathrm{V})$, after the challenge, tilapia were found fin rot and darkness color until the last experiment. The BP+V and $\mathrm{SF}+\mathrm{ZZ}+\mathrm{V}$ groups shown reducing the number of bacteria in the fish body after challenge test on $\mathrm{d} 7$, d14, and $\mathrm{d} 21$. The efficacy of Pseumulvacc vaccine has increased after its administration with BP (BP+V) on day 7 and day 14 after challenge $(90 \%)$ and $100 \%$ at the time of challenge test $\mathrm{d} 21$. The conclusion is $B$. pandurata extract was a promising adjuvant candidate, and the extract is the best plants as an adjuvant that mixed with the vaccine to against $A$. hydrophila and $P$. fluorescens infection.
\end{abstract}

Keywords: Adjuvant, plant extract, vaccine, fish pathogen bacteria

\begin{abstract}
ABSTRAK
Penelitian ini bertujuan mengevaluasi efek adjuvan dari ekstrak tanaman temu kunci (Boesenbergia panduratal BP), lempuyang (Zingiber zerumbet/ZZ), dan terung asam (Solanum ferox/SF) pada ikan nila yang diberikan bersama vaksin bakteri Pseudomonas sp. (Pseumulvacc). Dosis yang digunakan yaitu ekstrak BP 600 mg/L, ZZ $200 \mathrm{mg} / \mathrm{L}$, dan SF $900 \mathrm{mg} / \mathrm{L}$, dengan rasio antara vaksin dan ekstrak 1:1. Pengujian diawali dengan menginjeksi ikan nila dengan campuran vaksin dan ekstrak tanaman, dilanjutkan dengan uji tantang pada hari 7 (d7), 14 (d14) dan 21 (d21) pascavaksinasi dengan bakteri A. hydrophila dan P. fluorescens (kepadatan masing-masing 105 CFU/ $\mathrm{mL})$. Hasil pengujian menunjukkan ikan yang divaksin dengan penambahan ekstrak BP $(\mathrm{BP}+\mathrm{V})$ mengalami sirip gripis pada uji tantang hari ke-14, gejala serupa juga ditemukan pada pemberian vaksin yang dicampur dengan $\mathrm{ZZ}(\mathrm{ZZ}+\mathrm{V})$ pada waktu uji tantang d14, sebesar 11,11\% dan 42,86\%. Sedangkan, yang divaksin tanpa campuran ekstrak (V) mengalami sirip gripis dan menghitam pada uji tantang d14. Perlakuan $\mathrm{BP}+\mathrm{V}$ dan $\mathrm{SF}+\mathrm{ZZ}+\mathrm{V}$ mampu mengurangi jumlah bakteri di dalam tubuh ikan nila pasca uji tantang d7, d14 dan d21, dan jumlahnya lebih rendah dibandingkan dengan perlakuan lain. Efikasi vaksin Pseumulvacc mengalami peningkatan pada BP+V pada hari 7 dan hari 14 pasca ujitantang $(90 \%)$ dan $100 \%$ pada waktu uji tantang d21. Semakin lama uji tantang (d21), tingkat perlindungan vaksin plus ekstrak makin tinggi dibandingkan dengan hari d7 dan d14. Ekstrak B. pandurata adalah tanaman terbaik sebagai adjuvan untuk penanggulangan infeksi bakteri A. hydrophila dan P. fluorescens.
\end{abstract}




\section{INTRODUCTION}

The cultivation of tilapia grows rapidly, followed by the used for its rich source of protein (Wang et al., 2016), excellent gelatin source taken from the bone (Alfaro et al., 2013), or skin and scales (Jamilah \& Harvinder, 2002). It triggers the increase of intensive aquaculture production, which leads to the increasing number of mortality caused by pathogens, disruption of cultivated land sustainability, and the slowing growth (Kibenge et al., 2012).

Vaccination is a more environmental friendly in pathogen prevention technology compared to the application of antibiotics and other drugs (Sommerset et al., 2005; Rodger, 2016; Sukenda et al., 2018). In general, there are three methods for immunostimulant or vaccine application in fish include injection, immersion, and feed. Pasnik et al. (2005); Hardi et al. (2013); and Evensen (2016) stated that vaccination through intraperitoneal injection (IP) has a better efficacy rate than two other methods.

Giving the vaccine in combination with oilbased adjuvants would potentially improve vaccine efficacy in fish. Some of the adjuvant materials used in fish include Freund's adjuvants used with fish vaccine (Bøgwald \& Dalmo, 2012; Dalmo et al., 2016), EseD a Putative T3SS (Edwardsiella tarda has a type III secretion system) (Wang et al., 2010; Jiao et al., 2010b); Streptococcus agalactiae and Aeromonas hydrophila (Pasaribu et al., 2018). In addition, the use of other adjuvant mineral oils reported being effective in increasing the performance of Moritella viscosa vaccine and Aeromonas salmonicida in salmon (Mutoloki et al., 2010). Furthermore, non-oil material which also acts as adjuvant is aluminum salts (Jiao et al., 2010a), $\beta$-Glucans (Dalmo \& Bøgwald, 2008; Mizel \& Bates 2010); plant extract Quillaja saponaria saponin (Wang et al., 2016); a combination of Ocimum sanctum plant extract (Tulsi), Withania somnifera (Ashwagandha), Tinospora cordifolia (Guduchi), and Emblica officianalis (Amlaki) (Priyadarshini et al., 2012).

Saponin is steroids and terpenoid glycosides produced by several species of plants (Song, 2009; Sun et al., 2009; Tafalla et al., 2013) and could serve as specific adjuvants (Dalmo et al., 2016). This material has immunostimulant capabilities for animals including fish; is able to increase macrophage cell phagocytosis activity, antibody production, and produce cytotoxic T-lymphocytes (CTLs) which can inhibit exogenous antigen (Zhang et al., 2007; Xie et al.,
2008; Tam \& Roner, 2011;). According to Freitas et al. (2006) and Wang et al. (2016), the saponins from the $Q$. saponaria plant are non-toxic and capable of enhancing the specific immune system and tend to be immune protective in mixing with the Leishmania donovani vaccine. Saponin testing as an adjuvant has also been performed by Wang et al. (2016), the result indicated that the Vibrio anguillarum vaccine combined with $Q$. saponaria could enhance humoral antibody responses and increases the protective level of turbot (Scophthalmus maximus) fish after bacterial infection.

The Borneo plant extract of Boesenbergia pandurata (BP), Solanum ferox (SF), and Zingiber zerumbet (ZZ) are plants which easily grown in the yard and used as herbs plants by communities in east Kalimantan (Borneo). Based on previous research, that plant extracts containing saponins could serve as immunostimulants for tilapia (Hardi et al., 2016a,b and Hardi et al., 2017a,b). This study aimed to obtain information and test the associated potential adjuvant of $B$. pandurata extract, $S$. ferox, and Z. zerumbet in improving the efficacy of Pseumulvacc vaccine in tilapia.

\section{MATERIALS AND METHODS}

\section{Experimental fish}

The experimental fish sized about $15 \mathrm{~g}$ was tilapia originated from Seed Fishery Seedling Center Sebulu, Kutai Kartanegara District, which previously quarantined and isolated to ensure A. hydrohila and $P$. fluorescens free. The experimental fish was checked with A. hydrophila and $P$. fluorescens through isolating the gill and kidney in GSP media then incubated at $30^{\circ} \mathrm{C}$ for 18-21 hours. If the bacteria was not growth, the fish was ready to be used for this study, otherwise, if the bacteria was growth, the fish was immersed with formaline solutions $3 \%$ for five minutes (Kent et al., 2009).

\section{Plant material extraction}

Boesenbergia pandurata, Z. zerumbet, and $S$. ferox herbal materials were collected from the traditional market in Samarinda. The extraction process carried out using Limsuwan and Voravuthikunchai et al. (2008) and Hardi et al. (2016a) methods. The first step in extraction methods was cutting the plants into smaller pieces, oven-dried for four days or until dry and the air-dried plant samples were mashed using a blender. The dried samples were soaked in ethanol $(96 \%)$ at room temperature with the ratio 1:1 for 
48 hours. The extract solution was filtered with Whatman ${ }^{\circledR}$ filtration paper and the filtered sample was centrifuged for 24 hours at $50 \mathrm{rpm}$ to obtain a crude extract. The last step was to keep the crude extract in the oven $\left(30-40^{\circ} \mathrm{C}\right)$ until the ethanol lost from the extract, then the extract were kept in the refrigerator at $-4^{\circ} \mathrm{C}$ until used. The extract concentrations used were $600 \mathrm{mg} / \mathrm{L}$ B. pandurata, $900 \mathrm{mg} / \mathrm{L} S$. ferox and $200 \mathrm{mg} / \mathrm{L}$ Z. zerumbet (Sun et al., 2016a,b and Hardi et al., 2017a,b). The dose was achieved by diluting it using a sterile distilled water.

\section{Bacteria test}

Aeromonas hydrophila (EA-01) and $P$. fluorescens (EP-01) used as a bacterial test challenge, and Pseudomonas sp. as a bacterial vaccine came from the Microbiology Laboratory, Faculty of Fisheries and Marine Science, Mulawarman University, Indonesia. Bacteria were grown in the media brain heart infusion broth (BHIB DIFCO ${ }^{\circledR}$ ) and brain heart infusion agar (BHIA, DIFCO ${ }^{\circledR}$ ) for 24 hours at $30^{\circ} \mathrm{C}$.

The vaccine (Pseumulvacc) for Pseudomonas sp. bacteria was produced by inactivating using $3 \%$ formalin for 24 hours. The density of bacteria vaccine used was $10^{4} \mathrm{CFU} / \mathrm{mL}$ (Hardi et al., 2014b).

The bacteria for the challenge test used were a combination of $A$. hydrophila and $P$. fluorescens $1: 1$ ratio with the density of each bacterium $10^{5}$ CFU/mL (Hardi et al., 2017a). The administration was intramuscularly injected of $0.1 \mathrm{~mL} / \mathrm{fish}$ (Hardi et al., 2014a).

Effectiveness test of B. pandurata, S. ferox, and $Z$. zerumbet as an adjuvant of Pseumulvacc vaccine

Experiment test was conducted by mixing each extract with a vaccine ratio $1: 1$. This experiment consisted of 6 groups: (1) extract of B. pandurata mix with vaccine $(\mathrm{BP}+\mathrm{V})$; (2) Solanum ferox extract mix with vaccine $(\mathrm{SF}+\mathrm{V})$; (3) Zingiber zerumbet extract mix with vaccine $(\mathrm{ZZ}+\mathrm{V}) ;(4)$ concoction $S$. ferox and $Z$. zerumbet mix with vaccine $(\mathrm{SF}+\mathrm{ZZ}+\mathrm{V})$; (5) Vaccine without extract (V); (6) control group. This extract that using as an adjuvant in this research based on the preresearch, the concoction $S$. ferox, and $Z$. zerumbet was the best extract as an immunomodulatory extract than other concoction (B. pandurata and $S$. ferox or B. pandurata and Z. zerumbet).

Vaccine plus extract was injected to fish by intraperitoneal injection as many of $0.1 \mathrm{~mL} / \mathrm{fish}$. Challenge test was conducted on days 7,14 , and
21 post vaccination. The observations parameters were the percentage of fish undergoing changes in the anatomy of the external organs and internal organs, the total number of bacteria in the body of the tilapia fish, the total leucocyte, antibody titers, phagocytic index, and cumulative of mortality and RPS (relative percent survival).

\section{Fish pathology anatomy}

This parameter was done to evaluate the percentage of fish pathology anatomy post vaccination and challenge test. The observed fish pathology anatomy were fin rot, body darkness, and exophthalmia. The percentage of fish pathology anatomy was calculated according to Hardi et al. (2017 a,b) formula.

$$
\begin{gathered}
\text { Fish pathology } \\
\text { anatomy }
\end{gathered}=\frac{\text { Fish pathology anatomy }}{\begin{array}{c}
\text { Alive fish in the end of } \\
\text { treatment }
\end{array}} \times 100
$$

\section{Total bacteria}

Record the results for the total bacteria in the fish body after challenges test, calculate the mean colony count of five sample. As much $1 \mathrm{~g}$ of sample organ was crushed, then put into $9 \mathrm{ml}$ of sterile distilled water and continued by dilution $7,8,9$, and $1 \mathrm{ml}$ of suspense were grown on TSA agar medium, incubated at $30^{\circ} \mathrm{C}$ for 24 hours. The number of bacterial cells is calculated using colony number as Hardi et al. (2016a):

$$
\mathrm{N}=\frac{\mathrm{n} \times 300 \times \mathrm{f}}{\mathrm{m} \times \mathrm{X}} \times 100
$$

Note:

$\mathrm{N} \quad$ : The total colony number, (CFU/gram of dry mass

n : The mean colony count of five sample plates

F : The dilution factor

M : The weight of the test portion (gram)

$\mathrm{X}:$ : The dry matter content of the sample $(\%)$

\section{Total leucocyte}

Total leucocyte describes the number of leucocyte cells in the fish body after vaccine and challenge test with pathogenic bacteria (Blaxhall, 1972). The first step of total leucocyte examination has collected the blood from the fish, put into microtube and then the blood sample was sucked with a leucocyte pipette up to 0.5 and added Turk's solution into 11 scales, wiggling the pipette to 
homogeneously. Remove the first droplet, the next inserted the blood mix Turk's solution into the hemocytometer and cover with a cover glass, put on the microscope and accounted the cells. The number of leucocyte cells calculated on the five large boxes of hemocytometer and calculation by using the formula:

$$
\text { Total leucocyte }=\underset{\mathrm{mm}^{3}}{\sum \text { leucocyte cells }} \times 50 \text { cell } /
$$

\section{Antibody titers}

Serum preparation: fish blood was collected via caudal veins and put it in a micro tube, the next step was centrifuged at $3000 \mathrm{rpm}$ for 3 minutes. After the serum was separated from the blood cells, incubated at $44^{\circ} \mathrm{C}$ for 20 minutes to activate the complement (Lumsden et al., 1993). The serum was stored in a refrigerator at $4{ }^{\circ} \mathrm{C}$ for antibody titer observation.

The antibody titers measurements were carried out by taking $25 \mu \mathrm{L}$ of PBS solution and inserted into the microplate at holes $1^{\text {st }}$ through $12^{\text {th }}$, then inserting $25 \mu \mathrm{L}$ blood serum at $1^{\text {st }}$ hole and diluting the level up to $11^{\text {th }}$ hole. As much as $25 \mu \mathrm{L}$ of bacteria inserted into $1^{\text {st }}$ hole to $12^{\text {th }}$, then the microplate homogenized by gently waving. Further, it stored for two hours in the incubator at $37^{\circ} \mathrm{C}$, followed by storing into the overnight in refrigerator $4^{\circ} \mathrm{C}$, the antibody titers were determined from the last remaining hole of the agglutination reaction.

\section{Phagocytic index}

Phagocytic index was measured using Anderson and Siwicki (1995) method as much 50 $\mu \mathrm{L}$ of blood put into the microtube, added $50 \mu \mathrm{L}$ of a Staphylococcus aqueous suspension in PBS $\left(10^{7}\right.$ cells $\left./ \mathrm{mL}\right)$ was homogenized and incubated at room temperature for $20 \mathrm{~min}$. Make a prepared on the glass object and dry it out. Next step was fixing with methanol for five minutes and airdried, stained by immersion into Giemsa for 15 minutes, washed with running water and dried with tissue, and then observed and counted the number of cells showing the phagocytic process of 100 phagocyte cells observed.

\section{Cumulative mortality \& RPS}

The effectiveness of the extract as an adjuvant vaccine was measured by observing the fish mortality after challenges with A. hydrophila and P. fluorescens. Cumulative of mortality and RPS method using Ellis (1988) method.

$$
\begin{aligned}
& \begin{array}{c}
\% \text { Cumulative } \\
\text { of mortality }
\end{array}=\frac{\sum \begin{array}{c}
\text { mortality fish at the end } \\
\text { of the research }
\end{array}}{\sum \begin{array}{c}
\text { alive fish at the beginning } \\
\text { of the research }
\end{array}} \times 100 \\
& \text { RPS }=1-\left[\frac{\text { Percent mortality in treated group }}{\text { Percent mortality in control group }}\right] \times 100
\end{aligned}
$$

\section{Data analysis}

All results were presented in the average and standard deviation of three independent measurements. Cumulative mortality and RPS were analyzed using nonparametric ANOVA (SPSS 16 computer program) was used to determine whether there was a significant difference $(\mathrm{P}<0.05)$ compared to control and vaccine groups, while the hematological and immunological parameters were analyzed with description.

\section{RESULTS AND DISCUSSION}

\section{Results}

Fish pathology anatomy

Bacterial infections of $A$. hydrophila and Pseudomonas sp. causing exophthalmia symptoms in the eyes, fin rots and bleeding (Hardi et $a l ., 2014 \mathrm{a})$. The test results show that prevention of bacterial infection of A. hydrophila and P. fluorescens using vaccine mixed with plant extract reducing the fish symptoms such as fin rot, darkness and exophthalmia average decreased on day 14 post-challenge, and the results for all treatment were significantly different from vaccine without extract $(\mathrm{P}<0.05)$ on test challenges d21 (Table 1).

\section{Total bacteria in tilapia after the challenge test}

The number of bacteria in the fish body also decreased in the vaccinated without and mixed with the plant extract on day 14 after the challenge test. The highest decrease was found in the treatment of $\mathrm{SF}+\mathrm{ZZ}+\mathrm{V}$ reached $10^{3} \mathrm{CFU} / \mathrm{mL}$ and the result was significantly different from the un extracted vaccine $(\mathrm{V})(\mathrm{P}<0.05)$.

\section{Total leucocytes}

Post vaccination leucocyte types also increased, either with extracts or with no extracts. The increase in total leucocytes occurred from day 7 to day 21 after vaccination, and the highest increase occurred in indigo fish injected with a vaccine with a mixture of $S$. ferox and $Z$. zerumbet (Table 3).

Increased leucocytes occurred along with the formation of antibodies in fish after 5-10 days 
Table 1. The anatomical pathology of the outer organ of tilapia observation in day $14^{\text {th }}$ after post challenge test with bacteria A. hydrophila and P. fluorescens

\begin{tabular}{|c|c|c|c|c|}
\hline \multirow{2}{*}{ Group } & \multirow{2}{*}{ Pathology anatomy (\%) } & \multicolumn{3}{|c|}{ Challenges time } \\
\hline & & $\mathrm{d} 7$ & $\mathrm{~d} 14$ & $\mathrm{~d} 21$ \\
\hline \multirow{4}{*}{$\mathrm{BP}+\mathrm{V}^{*}$} & Fit rot & $0.00 \pm 0.5$ & $11.11 \pm 0.5$ & 0.00 \\
\hline & Darkness & $20 \pm 0.5$ & 0 & 0 \\
\hline & Exophthalmia & 0 & 0 & 0 \\
\hline & Fit rot & $16.67 \pm 0.5$ & 0 & 0 \\
\hline \multirow[t]{3}{*}{$\mathrm{SF}+\mathrm{V}^{*}$} & Darkness & 0 & 0 & 0 \\
\hline & Exophthalmia & 0 & 0 & 0 \\
\hline & Fit rot & $28.57 \pm 0.5$ & $42.86 \pm 0.5$ & 0 \\
\hline \multirow[t]{3}{*}{$\mathrm{ZZ}+\mathrm{V} *$} & Darkness & 0 & 0 & $10 \pm 0.5$ \\
\hline & Exophthalmia & 0 & 0 & 0 \\
\hline & Fit rot & 0 & $60 \pm 0.5$ & $40 \pm 0.5$ \\
\hline \multirow[t]{3}{*}{$\mathrm{SF}+\mathrm{ZZ}+\mathrm{V}^{*}$} & Darkness & 0 & $20 \pm 0.5$ & 0 \\
\hline & Exophthalmia & 0 & 0 & 0 \\
\hline & Fit rot & $50 \pm 0.5$ & $50 \pm 0.5$ & $30 \pm 0.5$ \\
\hline \multirow[t]{2}{*}{$\mathrm{V}^{*}$} & Darkness & $20 \pm 0.5$ & $10 \pm 0.5$ & 0 \\
\hline & Exophthalmia & 0 & 0 & 0 \\
\hline \multirow[t]{3}{*}{ Control } & Fit rot & 0 & 0 & 0 \\
\hline & Darkness & 0 & 0 & 0 \\
\hline & Exop hthalmia & 0 & 0 & 0 \\
\hline
\end{tabular}

Table 2. Total bacteria in tilapia organ observation in day $14^{\text {th }}$ after post challenge test with bacteria A. hydrophila and $P$. fluorescens

\begin{tabular}{cccc}
\hline \multirow{2}{*}{ Group } & \multicolumn{3}{c}{ Challenges time $(\mathrm{CFU} / \mathrm{mL})$} \\
\cline { 2 - 4 } BP + V* & Day- & Day-14 & Day-21 \\
$\mathrm{SF}+\mathrm{V}^{*}$ & $4.50 \pm 0.1 \times 10^{4}$ & $2.00 \pm 0.1 \times 10^{3}$ & $2.2 \pm 0.1 \times 10^{3}$ \\
$\mathrm{ZZ}+\mathrm{V}^{*}$ & $11.3 \pm 0.1 \times 10^{5}$ & $4.00 \pm 0.1 \times 10^{5}$ & $4.4 \pm 0.1 \times 10^{3}$ \\
$\mathrm{ZZ}+\mathrm{SF}+\mathrm{V}^{*}$ & $8.9 \pm 0.1 \times 10^{4}$ & $4.3 \pm 0.1 \times 10^{4}$ & $4.3 \pm 0.1 \times 10^{4}$ \\
$\mathrm{~V}^{*}$ & $4.5 \pm 0.1 \times 10^{4}$ & $2.1 \pm 0.1 \times 10^{4}$ & $2.2 \pm 0.1 \times 10^{3}$ \\
Control & $5.5 \pm 0.1 \times 10^{5}$ & $3.3 \pm 0.1 \times 10^{5}$ & $3.4 \pm 0.1 \times 10^{4}$
\end{tabular}

Note: BP (Boesenbergia pandurata), SF (Solanum ferox), ZZ (Zingiber zerumbet), and V (Vaccine Pseumulvacc)

Table 3. Total leukocytes at post-vaccination observation in day $14^{\text {th }}$ after post challenge with bacteria $A$. hydrophila and P. fluorescens

\begin{tabular}{cccc}
\hline \multirow{2}{*}{ Group } & \multicolumn{3}{c}{ Challenges time $\left(10^{5}\right.$ cells $\left./ \mathrm{mm}^{3}\right)$} \\
\cline { 2 - 4 } & Day-7 & Day-14 & Day-21 \\
\hline BP $+\mathrm{V}^{*}$ & $3.4 \pm 0.05$ & $4.5 \pm 0.04$ & $4.6 \pm 0.02$ \\
$\mathrm{SF}+\mathrm{V}^{*}$ & $2.9 \pm 0.07$ & $4.3 \pm 0.05$ & $4.4 \pm 0.03$ \\
$\mathrm{ZZ}+\mathrm{V}^{*}$ & $3.6 \pm 0.1$ & $3.9 \pm 0.059$ & $4 \pm 0.05$ \\
$\mathrm{ZZ}+\mathrm{SF}+\mathrm{V}^{*}$ & $3.8 \pm 0.06$ & $4.9 \pm 0.05$ & $5 \pm 0.05$ \\
$\mathrm{~V}^{*}$ & $3.0 \pm 0.04$ & $4.0 \pm 0.04$ & $4.1 \pm 0.05$ \\
Control & $1.6 \pm 0.05$ & $1.8 \pm 0.05$ & $1.8 \pm 0.03$
\end{tabular}

Note: BP (Boesenbergia pandurata), SF (Solanum ferox), ZZ (Zingiber zerumbet), and V (Vaccine Pseumulvacc) 
Table 4. Tilapia's antibody titers $\left(-\log ^{2}\right)$ at postvaccination observation in day $14^{\text {th }}$ after post challenge with bacteria A. hydrophila and P. fluorescens

\begin{tabular}{cccc}
\hline \multirow{2}{*}{ Group } & \multicolumn{3}{c}{ Titer antibody challenges time } \\
\cline { 2 - 4 } & Day-7 & Day-14 & Day-21 \\
\hline $\mathrm{BP}+\mathrm{V}^{*}$ & 4 & 5 & 6 \\
$\mathrm{SF}+\mathrm{V}^{*}$ & 3 & 4 & 5 \\
$\mathrm{ZZ}+\mathrm{V}^{*}$ & 3 & 5 & 5 \\
$\mathrm{ZZ}+\mathrm{SF}+\mathrm{V}^{*}$ & 4 & 5 & 6 \\
$\mathrm{~V}^{*}$ & 0 & 4 & 5 \\
Control & 0 & 0 & 0
\end{tabular}

Note: BP (Boesenbergia pandurata), SF (Solanum ferox), ZZ (Zingiber zerumbet), and V (Vaccine Pseumulvacc)
Table 5. Phagocytic index $(\%)$ observation in day $14^{\text {th }}$ after post challenge test with bacteria A. hydrophila and $P$. fluorescens

\begin{tabular}{cccc}
\hline \multirow{2}{*}{ Group } & \multicolumn{3}{c}{ Phagocytic index $(\%)$ challenges } \\
& time \\
\cline { 2 - 4 } & Day-7 & Day-14 & Day-21 \\
\hline $\mathrm{BP}+\mathrm{V}^{*}$ & $20.0 \pm 0.5$ & $60.2 \pm 0.2$ & $63.2 \pm 0.6$ \\
$\mathrm{SF}+\mathrm{V}^{*}$ & $22.2 \pm 0.2$ & $64.4 \pm 0.2$ & $62.2 \pm 0.5$ \\
$\mathrm{ZZ}+\mathrm{V}^{*}$ & $20.1 \pm 0.1$ & $64.4 \pm 0.5$ & $55.3 \pm 0.7$ \\
$\mathrm{ZZ}+\mathrm{SF}+\mathrm{V}^{*}$ & $22.2 \pm 0.3$ & $55.3 \pm 0.2$ & $55.3 \pm 0.1$ \\
$\mathrm{~V}^{*}$ & $20.0 \pm 0.1$ & $50.2 \pm 0.1$ & $49.3 \pm 0.2$ \\
Control & $10.1 \pm 0.2$ & $11.2 \pm 0.5$ & $12.1 \pm 0.3$ \\
\hline
\end{tabular}

Note: BP (Boesenbergia pandurata), SF (Solanum ferox), ZZ (Zingiber zerumbet), and V (Vaccine Pseumulvacc)

Table 6. Number of mortality and RPS of post-test indigo fish on day 7, 14 and 21 with bacteria A. hydrophila and P. fluorescens

\begin{tabular}{|c|c|c|c|c|c|c|}
\hline \multirow{3}{*}{ Group } & \multicolumn{6}{|c|}{ Challenges time } \\
\hline & \multicolumn{2}{|c|}{ Day-7 } & \multicolumn{2}{|c|}{ Day-14 } & \multicolumn{2}{|c|}{ Day-21 } \\
\hline & Mortality (\%) & RPS & Mortality (\%) & RPS & Mortality (\%) & RPS \\
\hline $\mathrm{BP}+\mathrm{V}^{*}$ & $10^{\mathrm{a}}$ & $90^{\text {cde }}$ & $10^{\mathrm{a}}$ & $91^{\text {bcde }}$ & $0^{\mathrm{abcd}}$ & $100^{\text {bcde }}$ \\
\hline $\mathrm{SF}+\mathrm{V}^{*}$ & $40^{\mathrm{bc}}$ & $48^{\mathrm{b}}$ & $40^{\mathrm{de}}$ & $50^{\mathrm{a}}$ & $0^{\mathrm{abcd}}$ & $100^{\text {bcde }}$ \\
\hline $\mathrm{ZZ}+\mathrm{V}^{*}$ & $30^{\mathrm{b}}$ & $61^{\mathrm{bcd}}$ & $20^{\mathrm{abc}}$ & $72^{\mathrm{bc}}$ & $0^{\mathrm{abcd}}$ & $100^{\text {bcde }}$ \\
\hline $\mathrm{ZZ}+\mathrm{SF}+\mathrm{V}^{*}$ & $40^{\mathrm{bcd}}$ & $52^{\mathrm{bc}}$ & $20^{\mathrm{abc}}$ & $72^{\mathrm{bc}}$ & $0^{\mathrm{abcd}}$ & $100^{\text {bcde }}$ \\
\hline $\mathrm{V}^{*}$ & $50^{\text {cde }}$ & $28^{\mathrm{a}}$ & $30^{\mathrm{bcd}}$ & $77^{\text {bcd }}$ & $20^{\mathrm{abcde}}$ & $80^{\mathrm{a}}$ \\
\hline
\end{tabular}

Note: BP (Boesenbergia pandurata), SF (Solanum ferox), ZZ (Zingiber zerumbet), and V (Vaccine Pseumulvacc). The same supercript letter indicated no significant difference $(\mathrm{P}>0.05)$.

post-vaccination. The formalin killed whole-cells of $S$. agalactiae and A. hydrophila bivalent mixed vaccine given through intraperitoneal injection in tilapia, Oreochromis niloticus was able to improve specific fish immune system and increase the value of RPS post-challenge test with $S$. agalactiae and $A$. hydrophila, or coinfection with both $S$. agalactiae and A. hydrophila (Pasaribu et al., 2018) .

\section{Antibody titers}

This research used a simple method to examine the antibody titer; Table 4 showed the result of value -log titer antibody. The results of measurement indicated that the value of fish antibody titer has already detected since 7 days after the test. However, the highest increase occurred on the $14^{\text {th }}$ day of the $21^{\text {st }}$ day test period increased up to 6 in the treatment using a mixture of $B$. pandurata as well as $S$. ferox and $Z$. zerumbet treatment, but the value was not significantly different between all treatments.

\section{Phagocytic index (\%)}

The results showed the number of cells that performed phagocytosis in the mixing treatment between the vaccine and the extract increased post-challenge compared with the vaccine without extract (Table 5). The highest increase occurred in the treatment with the addition of S. ferox and $Z$. zerumbet. The phagocytic index increased on day 14 and day 21.

\section{Cumulative mortality and RPS}

Tilapia test fish injected with bacteria $A$. hydrophila and P. fluorescens on day 7, 14 and 21post vaccination. Table 6 shows the cumulative mortality of tilapia. The entire tilapia fed with the mixture of extracts showed a decrease in the number of deaths compared to only vaccinated fish, ranging from seven days post-challenge test. When viewed from the post-challenge protective results, those seven days after the vaccination period has given the protection to the fish, and the better the protection as the challenge time (14 and 21 days post-vaccination) increases. Even 
the vaccine-administered fish plus the $B$. pandurata extract was able to provide $100 \%$ protection against fish post bacterial infections.

It seen from the RPS level, on the 7th day of the challenge test, the highest reached $90 \%$ in vaccine treatment plus the $B$. pandurata extract $(\mathrm{P}<0.05)$ (Table 6). It followed on the treatment of the 14th day tested vaccine with a $B$. pandurata mixture was able to increase the best RPS reached $91 \%$. However, in the $21^{\text {st }}$ day of the $21^{\text {st }}$ treatment, almost all vaccine treatments added with extracts were able to increase the RPS to $100 \%$ better than only the treated vaccine without the addition of extract (Table 6). The overall RPS results were significantly different from the non-extractive vaccine with $\mathrm{P}<0.05$. It turns out that the trial of using QSS as an adjuvant of the $V$. anguillarum vaccine in turbot fish indicating the same increasing in post-test RPS on days 14 and 28 (Wang et al., 2016).

\section{Discussion}

The utilization of adjuvant in vaccination to human (Pasquale et al., 2015; Wang et al., 2016) and fish (Bøgwald \& Dalmo, 2012) has already done for a long time, as it proved to increase the immunogenicity of the vaccine. Some ingredients which known as an adjuvant were aluminum, water-in-oil emulsions (Freund $>$ s adjuvants), part of microorganism cell and components of plant extracts (Rajput et al., 2007; Pasquale, 2015).

Plant extracts containing saponins, flavonoids, carbohydrates have the ability to immunomodulate fish such as B. pandurata, S. ferox and $Z$. zerumbet (Hardi et al., 2017a,b). Furthermore, Azadirachta indica extract, Ocimum sanctum, and Curcuma longa were able to increase the activity of phagocytosis, respiratory burst, and alternative complement activity and lysozyme goldfish (Carassius auratus) (Harikrishnan et al., 2009). Stratev et al. (2018) research showed that the treatment of fish pathogen infection using medicinal plants (secondary metabolites, fractions, or plant extracts) would be the best choice for sustainable aquaculture.

There are many of the phytocomponents of plant extracts, one of them is saponin which already proven to boost the fish's specific immune system when mixed with vaccines (Milgate \& Roberts, 1995; Song \& Hu, 2009; Bagherwal, 2011). The saponin component of $O$. aponaria extract was able to prevent rotavirus infection by inhibiting viral attachment of host cells, through the destruction of cell membrane proteins virus receptors (Tam et al., 2011). Saponin also stimulates growth and mucosal immune response that can prevent viral infections in humans (Wang et al., 2016; Tafalla et al., 2017). The results of the experiment by Wang et al. (2016) showed that utilization of Q. saponaria saponin (QSS) (45 mg/L) mixed with Vibrio anguillarum formalin vaccine increased the antibody production of Scophthalmus maximus on the $28^{\text {th }}$ day post vaccination. This indicated that QSS was capable as an adjuvant vaccine through immersion. QSS was able to increase the effectiveness of immune cells by increasing complement activity and macrophage cell phagocytosis capable of consequent antigen presenting activity, thereby initiating the downstream humoral adaptive immune responses of the immunized fish.

The results also showed that the administration of $B$. pandurata extract was able to increase antibody titer production, in accordance with the increasing of post-trial RPS with combined bacteria A. hydrophila and $P$. fluorescens extracts act as permeabilizing agents by which allowed the molecules penetrated into the cell, and have not been adequately addressed (Secombes \& Belmonte, 2016).

The addition of plant extracts increased the ability of antibodies to react with antigenic epitopes so that antigens were unable to recognize host cell receptors which would lead to failure of the antigen attachment process on the host cell surface (antibodies act as an inhibitor). In addition, the extract was also able to accelerate the elimination of antigen by the opsonizing process (antibody as opsonin). Formalin-killed E. tarda vaccine mixed with the Quil-A saponin increasing the survival rates after E. tarda infection and showed better survival. Adjuvant utilization mix with the fish vaccine was strongly capable to induce a specific immune response and long duration time protection, therefore the impact increased the vaccine efficiency (Tafalla et al., 2013).

\section{CONCLUSION}

The conclusion of this research was the $B$. pandurata extract was a potential adjuvant in the application of vaccine in freshwater fish. It was shown by the RPS after challenges was significantly higher than other treatment. The fish protection to bacterial infection was faster increase with B. pandurata administration (D7 and D14) than control (vaccine without extract). 


\section{ACKNOWLEDGMENTS}

Authors were grateful to the Mulawarman University Samarinda, for the award of IDB 4 in 1 Research Fellowship with the number 339/ UN17.11/PL/2017, which made this research possible. The authors were also grateful to the Department of Aquaculture, Faculty of Fisheries and Marine Science, Mulawarman University and Office of Marine and Fisheries Kutai Kartanegara, East Kalimantan for the facilities and cooperation.

\section{REFERENCES}

Alfaro AT, Balbinot E, Weber CI, Tonial IB, A-Lunkes M. 2014. Fish gelatin: Characteristics, functional properties, applicationsand future potentials. Food Engineering Reviews 6, 4: 93-96

Anderson DP, Siwicki AK. 1995. Basic hematology and serology for fish health programs. In:Shari M, Arthur JR, Subasinghe RP (eds). Diseases in Asian Aquaculture II. Fish Health Section, Asian Fisheries Society, Manila Philippines 185-202.

Bagherwal P. 2011. Phytosaponin adjuvants: A better option for vaccines. International Journal of Pharm Tech Research 3: 18371842.

Blaxhall PC. 1972. The haematological assessment of the health of freshwater fish: a review of selected literature. Journal of Fish Biology 4:593-604.

Bøgwald J, Dalmo RA. 2012. Developments in adjuvants for fish vaccines. Cambridge, UK: Woodhead Publishing Limited..

Dalmo R, Bøgwald J, Tafalla C. 2016. Adjuvants and delivery methods: current and novel. In: Adams A (eds) Fish Vaccines. Birkhäuser Advances in Infectious Diseases. Springer, Basel. pp. 75-104.

Dalmo RA, Bøgwald J. 2008. $\beta$-Glucans as conductors of immune symphonies. Fish and Shellfish Immunology 25: 384-396.

Ellis AE. 1988. Current aspects of fish vaccination. Diseases of Aquatic Organisms 4: 159-164.

Evensen Ø. 2016. Development of fish vaccines: focusing on methods. In: Adams A (eds) Fish Vaccines. Birkhäuser Advances in Infectious Diseases. Springer, Basel. pp. 53-74.

Freitas EO, Casas CP, Borja-Cabrera GB, Santos FN, Nico D, Souza LOP, Tinoco LW, da Silva BP, Palatnik M, Parente JP, Palatnik-de-Sousa CB. 2006. Acylated and deacylated saponins of Quillaja saponaria mixture as adjuvants for the FML-vaccine against Visceral leishmaniasis. Vaccine 24: 3909-3920.

Hardi EH, Sukenda, Harris E, Lusiastuti AM. 2013. Potential vaccine candidate of Streptococcus agalactiae for prevent strepcococosis on Nile tilapia (Oreochromis niloticus). Veteriner Journal 14: 408-416.

Hardi EH, Pebrianto CA, Hidayanti T, Handayani RT. 2014a. Phatogenicity of Aeromonas hydrophila via some port entry in cultured Nile tilapia, Oreochromis niloticus from Loa Kulu Kutai Kartanegara Kalimantan Timur. Jurnal of Kedokteran Hewan 8: 130-134.

Hardi EH, Saptiani G, Pebrianto CA. 2014b. Monovalen Pseudomonas sp. vaccine for fish disease control in aquaculture, Loa Kulu Kutaikartanegara Regency, East Kalimantan. Report of the results of universities applied research 2014 in East Kalimantan, Regional Research and Development Agency of East Kalimantan.

Hardi EH, Kusuma IW, Suwinarti W, Agustina, Abbas I, Nugroho RA. 2016a. Antibacterial activities of some Borneo plant extracts against pathogenic bacteria of Aeromonas hydrophila and Pseudomonas sp. AACL Bioflux 9: 638-646.

Hardi EH, Kusuma IW, Suwinarti W, Agustina, Nugroho RA. 2016b. Antibacterial activity of Boesenbergia pandurata, Zingiber zerumbet and Solanum ferox extracts against Aeromonas hydrophila and Pseudomonas sp. Nusantara Bioscience 8: 18-21.

Hardi EH, Saptiani G, Kusuma IW, Suwinarti W, Nugroho RA. 2017a. Immunomodulatory and antibacterial effects of Boesenbergia pandurata, Solanum ferox, and Zingiber zerumbet on tilapia, Oreochromis niloticus. AACL Bioflux 10: 182-190.

Hardi EH, Kusuma IW, Suwinarti W, Saptiani G, Sumoharjo, Lusiastuti AM. 2017b. Utilization of several herbal plant extracts on Nile tilapia in preventing Aeromonas hydrophila and Pseudomonas sp. bacterial infection. Nusantara Bioscience 9: 220-228.

Harikrishnan R, Balasundaram C, Kim MC, Kim JS, Han YJ, Heo MS. 2009. Innate immune response and disease resistance in Carassius auratus by triherbal solvent extracts. Fish \& Shellfish Immunology 27: 508-515.

Harikrishnan R, Balasundaram C, Heo MS. 2010. Herbal supplementation diets on hematology and innate immunity in goldfish against 
Aeromonas hydrophila. Fish \& Shellfish Immunology 28: 354-361.

Jamilah B, Harvinder KG. 2002. Properties of gelatins from skin of fish-black tilapia Oreochromis mossambicus and red tilapia Oreochromis niloticus. Food Chemistry 77: 81-84.

Jiao XD, Cheng S, Hu YH, Sun L. 2010a. Comparative study of the effects of aluminium adjuvants and Freund's incomplete adjuvant on the immune response to an Edwardsiella tarda major antigen. Vaccine 28: 1832-1837.

Jiao XD, Hu YH, Sun L. 2010b. Dissection and localization of the immunostimulating domain of Edwardsiella tarda flic. Vaccine 28: 56355640.

Kibenge FSB, Godoy MG, Fast M, Workenhe S, Kibenge MJT. 2012. Countermeasures against viral diseases of farmed fish. Antiviral Research 95: 257-281.

Lumsden JS, Ostland VE, Byrne PJ, Ferguson HW. 1993. Detection of a distinct gill-surface antibody response following horizontal infection and bath challenge of brook trout Salvelinus fontinalis with Flavobacterium branchiophilum, the causative agent of bacterial gill disease. Diseases of Aquatic Organisms 16: 21-27.

Milgate J, Roberts DCK. 1995. The nutritional \& biological significance of saponins. Nutrition Research 15: 1223-1249.

Mutoloki S, Cooper GA, Marjara IS, Koop BF, Evensen Ø. 2010. High gene expression of inflammatory markers and IL-17A correlates with severity of injection site reactions of Atlantic salmon vaccinated with oiladjuvanted vaccines. BMC Genomics 11: 336.

Pasaribu W, Sukenda, Nuryati S. 2018. The efficacy of Nile tilapia Oreochromis niloticus broodstock and larval immunization against Streptococcus agalactiae and Aeromonas hydrophila. Fishes 3: 1-14.

Pasnik DJ, Evans JJ, Panangala VS, Klesius PH, Shelby RA, Shoemaker CA. 2005, Antigenicity of Streptococcus agalactiae extracellular products and vaccine efficacy. Journal of Fish Diseases 28: 205-212.

Pasquale AD, Preiss S, de Silva FT, Garcon N. 2015. Vaccine adjuvants: from 1920 to 2015 and beyond. Vaccines 3: 320-343.

Priyadarshini M, Manissery JK, Mohan CV, Keshavanath P. 2012. Effect of immuplus on growth and inflammatory response to Fruend's complete adjuvant in common carp, Cyprinus carpio (L.). Turkish Journal of Fisheries and Aquatic Sciences 12: 291-299.

Kent ML, Feist SW, Harper C, Hoogstraten-Miller S, Law JW, Sánchez-Morgado JM, Robert L, Tanguay, Sanders GE, Spitsbergen JM, Whipps CM. 2009. Recommendations for control of pathogens and infectious diseases in fish research facilities. Comparative Biochemistry and Physiology - Part C: Toxicology \& Pharmacology 149(2): 240-248.

Mizel SB, Bates JT. 2010. Flagellin as an adjuvant: cellular mechanisms and potential. The Journal of Immunology 185: 5677-5682.

Rajput ZI, Hu S, Xiao C, Arijo AG. 2007. Adjuvant effects of saponins on animal immune responses. Journal of Zhejiang University Science B8 3:153-161.

Rodger HD. 2016. Fish disease causing economic impact in global aquaculture. In: Adams A. (eds) Fish Vaccines. Birkhäuser Advances in Infectious Diseases. Springer, Basel. pp. 1-34.

Secombes CJ, Belmonte R. 2016. Overview of the fish adaptive immune system. In: Adams A (eds) Fish Vaccines. Birkhäuser Advances in Infectious Diseases. Springer, Basel. pp. 3552.

Song X, Hu S. 2009. Adjuvant activities of saponins from traditional Chinese medicinal herbs. Vaccines 27: 4883-4890.

Stratev D, Zhelyazkov G, Noundou XS, Krause RWM. 2018. Beneficial effects of medicinal plants in fish diseases. Aquaculture International 26: 289-308.

Sukenda, Rahman, Nisaa K, Hidayatullah D, Vinasyiam A. 2018. The efficacy of Streptococcus agalactiae vaccine preparations, administered to tilapia broodstock, in preventing streptococcosis in their offspring, via transfer of maternal immunity. Aquaculture International 26: 252-256.

Sommerset I, Kross $\varnothing y$ B, Biering E, Frost P. 2005. Vaccines for fish in aquaculture. Expert Review Vaccines 4:89-101.

Sun HX, Xie Y, Ye YP. 2009. Advances in saponin based adjuvants. Vaccine 27: 1787-1796.

Tafalla C, Bøgwald J, Dalmo RA. 2013. Adjuvants and immunostimulants in fish vaccines: current knowledge and future perspectives. Fish and Shellfish Immunology 35: 1740-1750.

Tafalla C, González L, Castro R, Granja AG. 2017. $B$ cell-activating factor regulates different aspects of $\mathrm{B}$ cell functionality and is produced by a subset of splenic B cells in teleost fish. Frontiers in Immunology 8:295-300 
Tam KI, Roner MR. 2011. Characterization of in vivo anti-rotavirus activities of saponin extracts from Quillaja saponaria Molina. Antivirus Research 90: 231-241.

Voravuthikunchai SP, Okada K, Iida T, Honda T. 2008. Early diagnosis of infectious diarrhea using lactoferrin and hemoglobin markers. Journal of Rapid Methods \& Automation in Microbiology 16,4:135-145.

Wang B, Mo ZL, Xiao P, Jie Li, Zou YX, Bin Hao, Li GY. 2010. EseD, a Putative T3SS Translocon Component of Edwardsiella tarda, Contributes to Virulence in fish and is a candidate for vaccine development. Journal of Marine Biotechnology12: 678-685.

Wang Y, Wang X, Huang J, Jun Li. 2016. Adjuvant
Effect of Quillaja saponaria Saponin (QSS) on protective efficacy and IGM generation in turbot Scophthalmus maximus upon immersion vaccination. International Journal of Molecular Sciences 17: 325-338.

Xie Y, Deng W, Sun H, Li D. 2008. Platycodin D2 is a potential less hemolytic saponin adjuvant eliciting Th1 and Th2 immune responses. International Immunopharmacology 8: 11431150.

Zhang XF, Cui Y, Huang JJ, Zhang YZ, Nie Z, Wang LF, Yan BZ, Tang YL, Liu Y. 2007. Immuno-stimulating properties of diosgenyl saponins isolated from Paris polyphylla. Bioorganic and Medicinal Chemistry Letters 17: 2408-2413. 